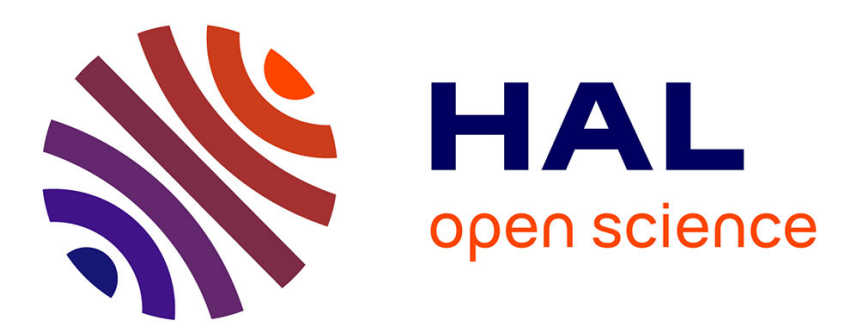

\title{
Molecular Dynamics Studies of Concentrated Binary Solutions of Lanthanide Salts: Structural and Exchange Dynamics
}

Magali Duvail, Alexandre Ruas, Laurent Venault, Philippe Moisy, Philippe Guilbaud

\section{To cite this version:}

Magali Duvail, Alexandre Ruas, Laurent Venault, Philippe Moisy, Philippe Guilbaud. Molecular Dynamics Studies of Concentrated Binary Solutions of Lanthanide Salts: Structural and Exchange Dynamics. Inorganic Chemistry, 2010, 49 (2), pp.519-530. 10.1021/ic9017085 . cea-00870636

\section{HAL Id: cea-00870636 https://hal-cea.archives-ouvertes.fr/cea-00870636}

Submitted on 7 Oct 2013

HAL is a multi-disciplinary open access archive for the deposit and dissemination of scientific research documents, whether they are published or not. The documents may come from teaching and research institutions in France or abroad, or from public or private research centers.
L'archive ouverte pluridisciplinaire HAL, est destinée au dépôt et à la diffusion de documents scientifiques de niveau recherche, publiés ou non, émanant des établissements d'enseignement et de recherche français ou étrangers, des laboratoires publics ou privés. 


\title{
Molecular Dynamics Studies of Concentrated Binary Aqueous Solutions of Lanthanide Salts: Structures and Exchange Dynamics
}

\author{
Magali Duvail, Alexandre Ruas, Laurent Venault, Philippe Moisy and Philippe Guilbaud* \\ CEA, Nuclear Energy Division, RadioChemistry \& Processes Department \\ F-30207 Bagnols sur Cèze, France
}

Inorg. Chem., 2010, 49 (2), pp 519-530

DOI: $10.1021 /$ ic9017085

Publication Date (Web): December 21, 2009

Concentrated binary aqueous solutions of lanthanide $\left(\mathrm{Nd}^{3+}\right.$ and $\mathrm{Dy}^{3+}$ salts $\left(\mathrm{ClO}_{4}^{-}, \mathrm{Cl}^{-}\right.$, and $\left.\mathrm{NO}_{3}{ }^{-}\right)$ have been studied by means of classical molecular dynamics (MD) simulations with explicit polarization and UV-visible spectroscopy. Pair interaction potentials, used for the MD simulations, have been developed in order to reproduce experimental hydration properties. $\mathrm{Nd}^{3+}$ and $\mathrm{Dy}^{3+}$ have been chosen because of their position in the lanthanide series: $\mathrm{Nd}^{3+}$ being a light lanthanide and $\mathrm{Dy}^{3+}$ a heavy one. They are respectively coordinated to nine and eight water molecules, in pure water, involving changes in their salt hydration structures. Both MD simulations and UV-visible experiments highlight the stronger affinity of nitrate anions toward $\mathrm{Ln}^{3+}$ compared to perchlorates and chlorides. Dissociation/association processes of $\mathrm{Nd}^{3+}-\mathrm{Cl}^{-}$and $\mathrm{Nd}^{3+}-\mathrm{NO}_{3}{ }^{-}$ion pairs in aqueous solution have been analyzed using potential of mean force profile calculations. Furthermore, from MD simulations, it appears that the affinity of anions (perchlorate, chloride, and nitrate) is stronger for $\mathrm{Nd}^{3+}$ than $\mathrm{Dy}^{3+}$.

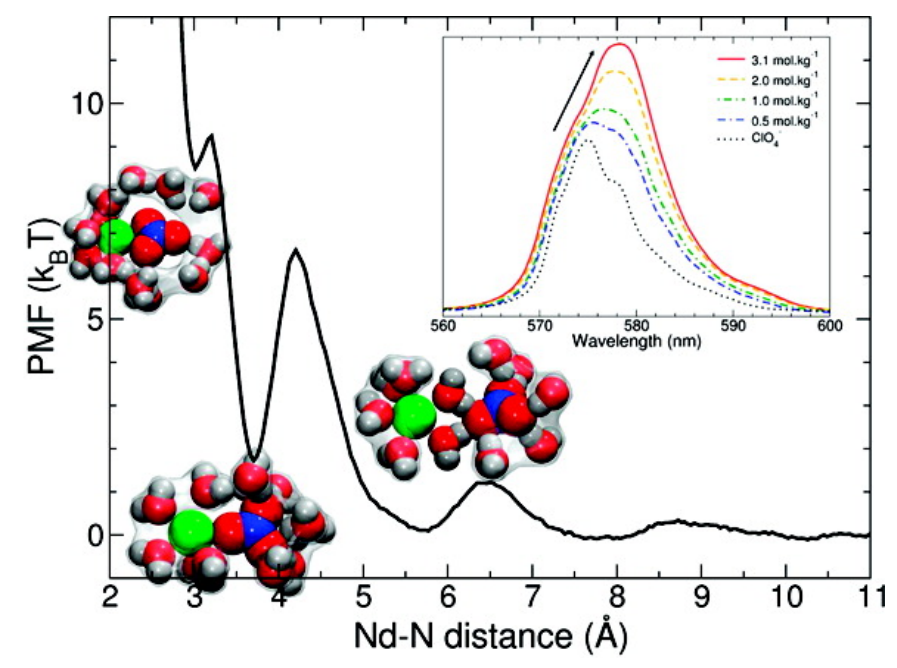

